\title{
THE LOPHOPHORE AND CILIARY FEEDING MECHANISMS OF THE BRACHIOPOD CRANIA ANOMALA (MULLER)
}

\author{
By the late D. Atkins, ${ }^{1}$ D.Sc. \\ The Plymouth Laboratory \\ and M. J. S. Rudwick \\ Sedgwick Museum, Cambridge
}

(Text-figs. $\mathrm{I}-4$ )

Specimens of Crania anomala (Müller) were dredged on several cruises by R.V. 'Sarsia' from La Chapelle Bank. Some of the work was done on specimens kindly sent by Dr G. Owen from near Garbh Reisa, off Craignish Point, Argyllshire.

Crania is one of the few living brachiopods that are attached to the substratum by cementation. In $C$. anomala the whole ventral valve is cemented to the surface of a rock, stone or shell, and the dorsal valve assumes a limpetlike form above it. Rowell (I960) has described the character of a typical locality for the species: rocky current-swept bottoms in moderately shallow water are the usual habitat.

\section{THE ADULT LOPHOPHORE}

\section{The ciliation of the filaments}

Crania anomala was the first, and remained for many years the only, brachiopod species in which the ciliary feeding mechanism had been investigated. Orton (1914) showed that the row of long slender filaments on the lophophore constitutes a filter-feeding device, with lateral cilia drawing water through the narrow gaps between the filaments, and frontal cilia carrying particles to the base of the filaments for subsequent transport to the mouth.

\footnotetext{
${ }^{1}$ Dr Daphne Atkins died on 31 March 196r. Through the courtesy of Dr F. S. Russell I have been able to look through her unpublished papers. The nucleus of the present paper is a short typescript, on the adult lophophore of Crania anomala (Müller), which she wrote and sent to me for comment in 1957; but it has been possible to amplify this from her other MS. notes on Crania, from my own studies of this brachiopod at Plymouth in 1954, and from our correspondence and discussions between I954 and 1960. I have also taken the opportunity to relate this work to other recently published studies of brachiopods, and to suggest some general conclusions. Figs. 2-4 are re-drawn from Dr Atkins's pencilled camera-lucida drawings; Fig. I is my own.

M. J. S. Rudwick 
Behind the mouth there are about fourteen filaments lying in a single row; these have ridged frontal surfaces. On the rest of the brachia the filaments are in two series, being alternately nearer and farther from the food-groove. As in other species, those nearer the food-groove have ridged frontal surfaces; those farther from the groove are broader and have a shallow groove running down the frontal surface (see Orton, 19I4, fig. 7). The grooved filaments are generally longer than the ridged: this is especially noticeable on the proximal whorl of each brachium (Figs. 2, 4).

The frontal cilia are $20-25 \mu$ in length. Normally they beat towards the base of the filament, carrying particles towards the food groove. But thick suspensions of Chlorella, carborundum powder or graphite induce reversal of the cilia. As in articulate brachiopods, this is definitely true reversal, and is not due, as Chuang (1956) claims in Lingula, to closely adjacent tracts of cilia beating in different directions. Reversal is obtained more easily on the ridged than on the grooved filaments: sometimes particles can be seen passing towards the tips of the ridged filaments while they are passing towards the base of the grooved ones. The beating of the frontal filaments seems to be continuous. It can be studied on a severed portion of the lophophore or even on a single severed filament; and it is only slowly inhibited by the rising temperature and salinity of a preparation which is illuminated for study under the microscope.

The lateral cilia are $25-30 \mu$ long and densely distributed along narrow zones on the lateral surfaces of both series of filaments. In the intact animal they beat very strongly, with a good metachronal wave. The plane in which they beat is at right angles to the length of the filaments, from the frontal surface towards the abfrontal. Reversal has not been observed. Unlike the frontal cilia they appear to be under nervous control. They stop beating if thick suspensions of particles are introduced, and often - though not invariably - when a portion of the lophophore is cut off for study under the microscope.

Abfrontal cilia are much more sparsely distributed than the other tracts. They produce no obvious current, and seem to be normally inactive. Some are about $18 \mu$ in length, and normally lie prone, with their tips pointing towards the tip of the filament; but occasionally they were seen to beat towards the base. Some of the cilia are distinctly shorter (about 10 $\mu$ ) and are normally held erect: possibly they are sensory.

\section{The orientation of the lophophore, and the current-system}

The anatomy of the adult lophophore of $C$. anomala was described in detail by Blochmann (I892) and need not be discussed here.

In all brachiopods the lophophore, and especially the filaments, become badly distorted during fixation, unless carefully narcotized beforehand. It is therefore almost impossible to interpret the lophophore correctly from speci- 
mens preserved without narcotization. The following description is based on observations on undisturbed living specimens and on those in which the lophophore was relaxed by narcotization (with $\mathrm{I} \%$ Stovaine) before fixation.

When the shell is open and the animal is feeding, the lophophore is well extended (Figs. I, 2). The two brachia form low conical spirals, the apices of which project dorsally into the interior of the conical dorsal valve. The filaments near the mouth project obliquely forwards, touching the ventral mantle surface. Traced laterally, the filaments change their orientation and project outwards. In the antero-lateral portion of the first or proximal whorl on each brachium, the filaments are very long; they touch the edge of the dorsal mantle, but their tips project well beyond the edge and are gently flexed dorsally. Anteriorly, they no longer touch the dorsal mantle; and near the median plane they may approach or even touch the ventral mantle. Beyond this point the proximal whorl on each brachium curves posteriorly, and its filaments here project inwards and interdigitate in the median plane.

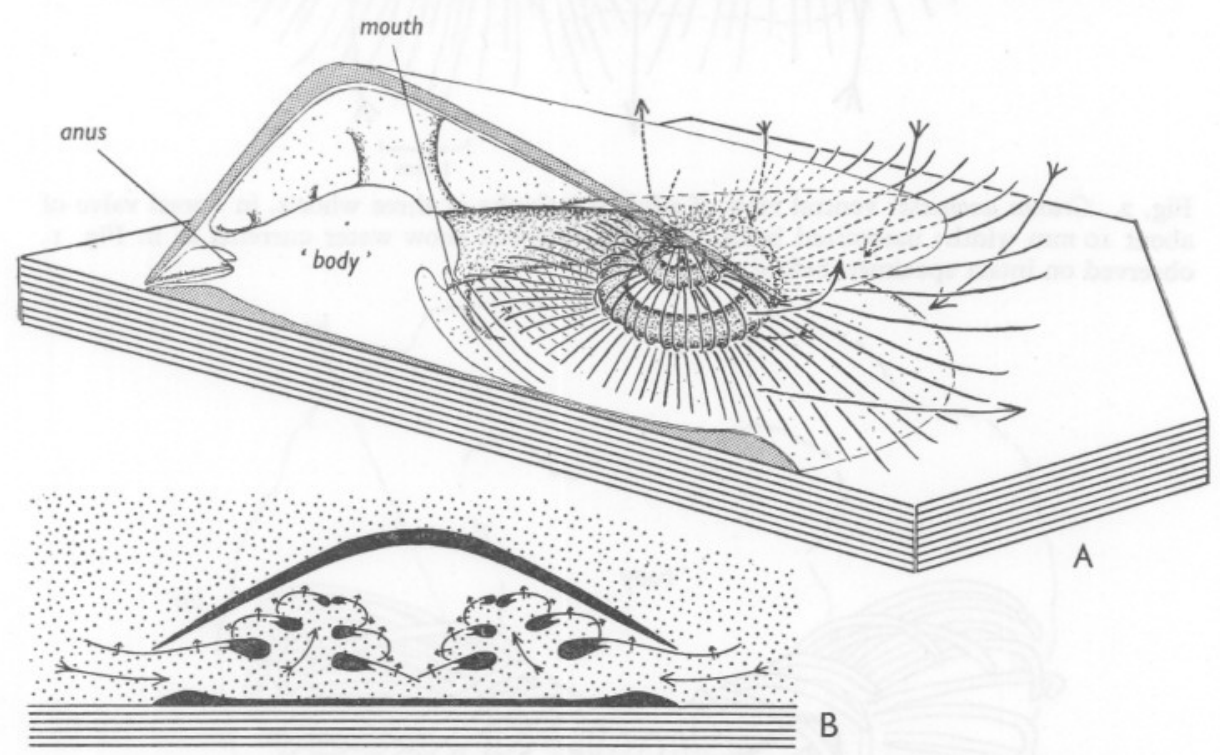

Fig. I. Crania anomala in feeding position. A. Diagrammatic oblique view of left side of animal, cut along median plane, to show natural orientation of filaments and body of lophophore, and course of water currents. For the sake of clarity, filaments are represented with much wider spacing than natural, and dorsal valve is represented as though transparent. Feathered arrows represent inhalant currents of unfiltered water; unfeathered arrows, exhalant currents of filtered water. Sections of valves regularly stippled, with ventral valve cemented to substratum; section of 'body' left blank. B. Diagrammatic transverse section through spiral axes, to show orientation of filaments and division of mantle cavity into inhalant chamber with unfiltered water (irregular stippling) and exhalant chamber with filtered water (blank). Feathered arrows show currents in inhalant chamber; small arrows show direction of filtration between filaments. Shell, mantle and body of lophophore black. Based on observations of living animal in feeding position, and narcotized specimens. Compare with Fig. 2. 


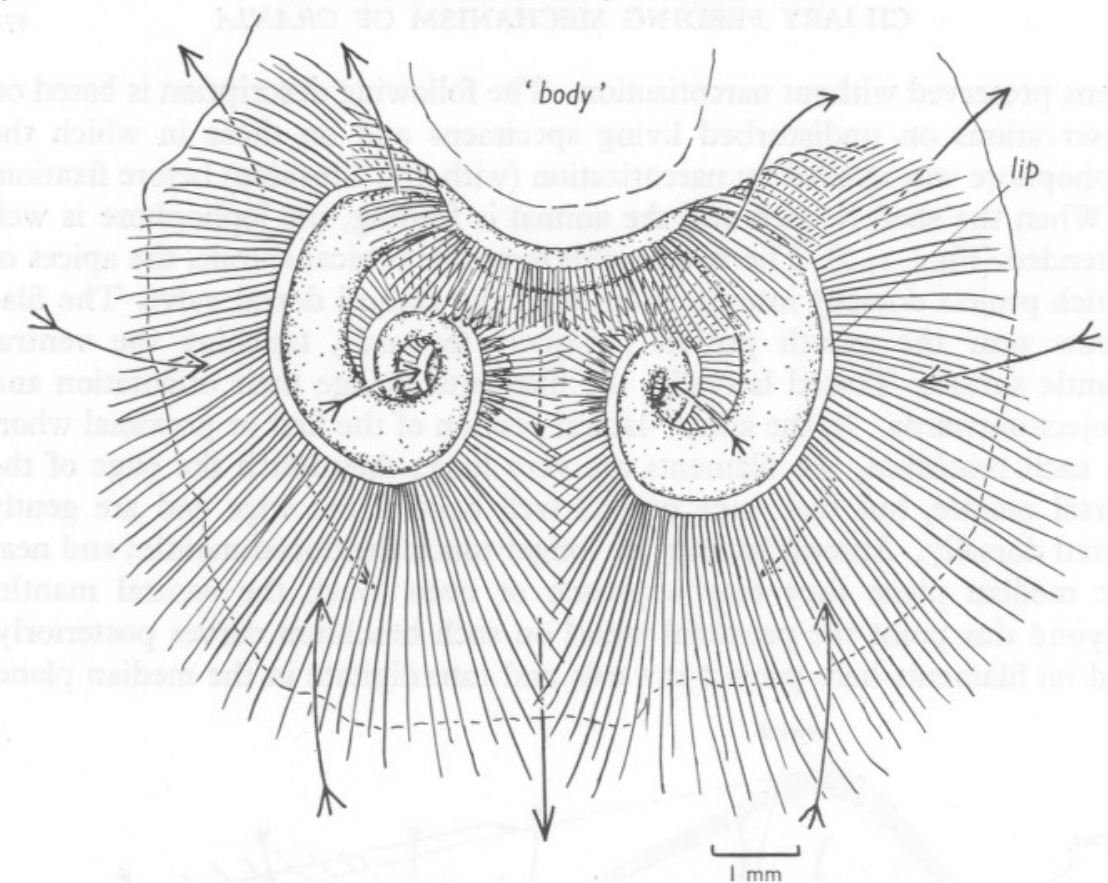

Fig. 2. Crania anomala: ventral view of adult spirolophe of three whorls, in dorsal valve of about ro mm width; narcotized before opening. Arrows show water currents as in Fig. I, observed on intact specimen before opening.

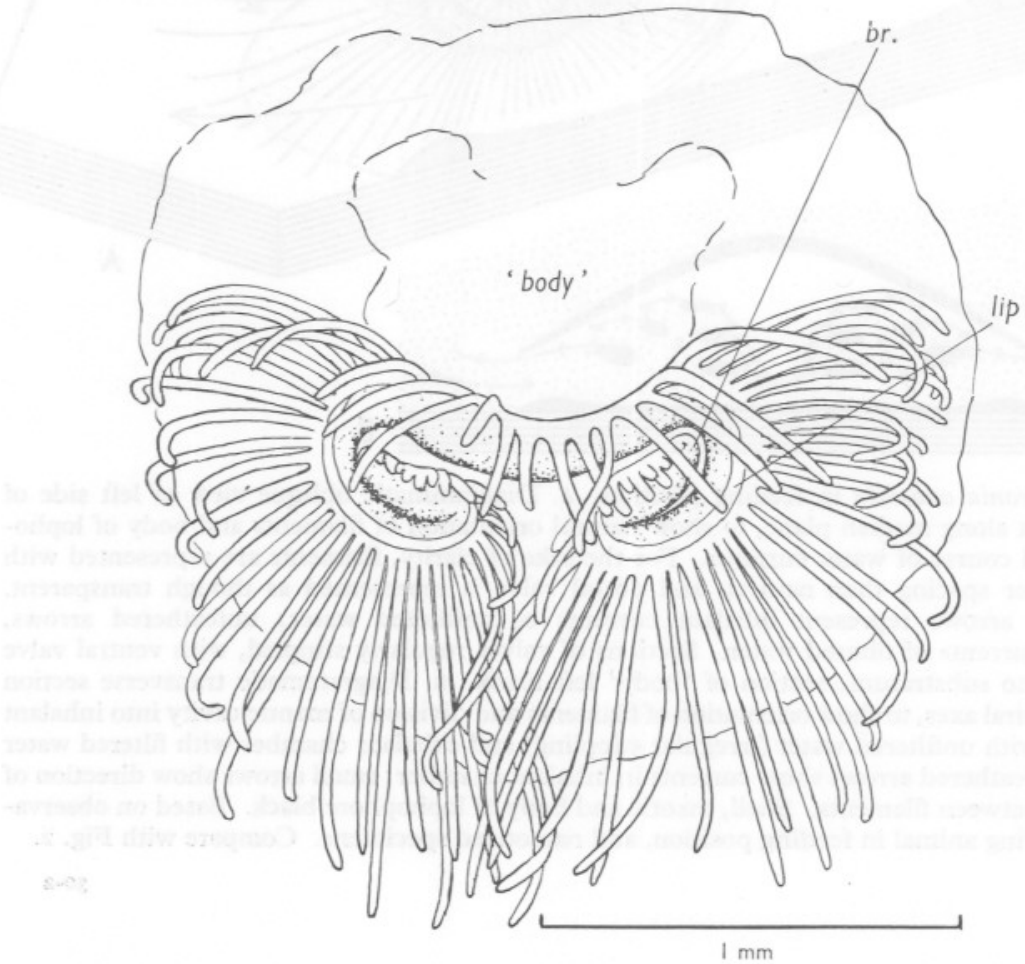

Fig. 3. Crania anomala: ventral view of very early spirolophe, in dorsal valve of about $2 \mathrm{~mm}$ width; imperfectly narcotized before opening. About forty-five pairs of filaments. $b r$., tip of brachium. 
At the beginning of the second whorl on each side, they become gently flexed towards their frontal sides (i.e. ventrally), and their tips touch the body of the lophophore immediately in front of the mouth. Beyond this point, and over the rest of the lophophore, the filaments are strongly flexed, so that their tips touch the bases of the filaments of the preceding whorl.

This arrangement of the filaments divides the whole mantle cavity into two distinct chambers (Fig. I, B); an inhalant chamber chiefly on the ventral side of the mantle cavity, but extending dorsally into the interior of the spirals; and an exhalant chamber chiefly on the dorsal side of the mantle cavity, but extending to the ventral mantle surface in the region behind the mouth. The frontal sides of all the filaments face into the inhalant chamber, and the action of the lateral cilia draws water through the gaps between the filaments, from the inhalant chamber into the exhalant.

A further result of the orientation of the filaments is that the gape between the valve edges is divided into five apertures: two lead into the inhalant chamber and three into the exhalant. Water enters the inhalant chamber through two broad antero-lateral apertures, each of which is bounded on one side by the ventral mantle edge and on the other by the antero-lateral filaments on the proximal whorl. It may then be filtered through the screen of filaments there; or else it passes up the interior of the spiral and is filtered outwards through the screen of filaments on one of the distal whorls. Having entered the exhalant chamber, the water flows towards one of the three exhalant apertures. There is an antero-median aperture, bounded by the dorsal mantle edge and by the anterior filaments on the proximal whorls of both brachia; and there are two postero-lateral exhalant apertures, each bounded by both mantle edges and by the postero-lateral filaments on the proximal whorl. The relative size and importance of the median and lateral exhalant apertures depends on the exact orientation of the filaments on the proximal whorls; this seems to vary in different specimens, and also depends on the degree of opening of the valves, which varies at different times in the same specimen. Sometimes the median aperture is very small, and the two inhalant apertures may coalesce on its ventral side. Nevertheless, all three exhalant apertures were invariably present in some degree in all the specimens we have examined.

The foregoing description differs in certain respects from the account given by Orton. The most important difference lies in the orientation given to the filaments on the distal whorls. Orton showed these filaments projecting straight outwards, away from the axis of the spiral, like those on the proximal whorl of each brachium (Orton, I9I4, fig. 4). These distal filaments are not easy to see in an undisturbed living specimen, though if the shell is suitably oriented they can sometimes be glimpsed through the gape between the valve edges. So it is possible that Orton never actually saw the natural orientation of the distal filaments, but inferred that they projected outwards like those on 
the proximal whorl-which he could see in the natural state. From this inference it would follow, as he stated, that the water must be filtered repeatedly by the filaments on successive whorls; and thus the mantle cavity would not be divided into separate chambers. If this were so, Crania would differ not only from all other brachiopods whose feeding mechanisms have been studied since Orton's work, but also from other animals with an enclosed ciliary feeding organ (e.g. molluscs, protochordates). In all these, the feeding organ divides inhalant spaces or chambers from exhalant, and the water is filtered only once. On the grounds of this general analogy, Rudwick suggested that Orton's account might be erroneous at this point; and this was subsequently confirmed by Atkins by direct observation through the gape of undisturbed living specimens.

A forcible opening of the shell without narcotization results in an unnatural contraction not only of the filaments but also of the body of the lophophore. In the natural state the spiral brachia are more loosely coiled than Orton showed them to be, so that there is ample space for a current to flow up their interior. The specimens he studied may have been some in which the posterolateral exhalant apertures were much smaller than the median aperture, for he mentioned only the latter.

\section{The opening and closing of the shell}

The filter-feeding system operates, of course, only while the valves are gaping apart. Although Crania, as an inarticulate, lacks the rigid hinge (of teeth and sockets) of an articulate brachiopod, the posterior side of the shell nevertheless functions as a rudimentary hinge. When the shell opens, it does so by a rotation of the dorsal valve about an axis corresponding to the posterior side of the shell, where the valve edges remain in contact. It is not entirely clear how this rotation is produced; for unlike an articulate brachiopod there are no divaricator muscles acting behind the hinge axis, and unlike a bivalve mollusc there is no ligament. It is possible that the elasticity of the muscle fibres is sufficient by itself to expand the length of the massive columnar adductor muscles, and so to raise the dorsal valve, once the stimulus for contraction is removed. The shell can be closed quite rapidly when the animal is disturbed: like other brachiopods Crania is especially sensitive to vibration. When this occurs the filaments projecting beyond the valve edges are withdrawn very rapidly into the mantle cavity, by the contraction of the strand of striated muscle which runs up the frontal side of each filament. Sometimes, however, the shell closes more slowly and without apparent external stimulus. On these occasions the dorsal valve is not drawn straight down on to the ventral, but swivels gently from side to side as it approaches the ventral valve, as though adjusting its position to ensure a tight fit. This movement is undoubtedly due to the action of the oblique muscles (see Blochmann, I892, Taf. I, fig. 9; Bulman, I939, text-fig. 4). 


\section{DEVELOPMENT OF THE LOPHOPHORE}

\section{Trocholophous and schizolophous stages}

Rowell (1960) has recently described some of the earlier growth stages of C. anomala. He found no specimens with fewer than three pairs of filaments on the lophophore. Percival's (I960) description of the comparable stages in Tegulorhynchia nigricans (Sowerby) suggests a possible reason: for in this rhynchonellid the first three pairs of filaments develop simultaneously from the embryonic apical lobe. At this earliest known stage in Crania the filaments are already ciliated laterally and frontally, and have a central filamentar canal with a muscle strand on the frontal side. There is a rudimentary lip in front of the mouth. New pairs of filaments are then added symmetrically, as in other brachiopods, on the anterior side of the lophophore. Although Rowell does not mention this point, the filaments are presumably added in a single row up to the stage with about seven pairs and thereafter in the usual alternation of ridged and grooved series: this would account for the presence of some fourteen filaments in a single row near the mouth in later growth stages and in the adult.

By the time that there are nine pairs, Rowell notes that the anterior growth region is beginning to split laterally into the two growth regions of the future brachia. The brachia are clearly separate when there are twelve or thirteen pairs of filaments, and the lophophore has become bilobed or schizolophous. With further growth the brachia begin to assume the spiral form of the adult lophophore, the first or proximal whorl being completed when there are about twenty pairs of filaments. By this stage the lip of the food groove extends from the mouth to the tips of the brachia.

Rowell's description is based on preserved specimens in which the filaments are contracted; but it is probable that in the natural state the filaments of the trocholophous and schizolophous stages project forwards in a bell-like form, as in other brachiopods (e.g. Atkins, 1956, 1958; Rudwick, 1962).

\section{Spirolophous stage}

The smallest specimens available to us were at a growth stage somewhat beyond the last (twenty-pair) stage described by Rowell. At the first stage figured here (Fig. 3) there are about forty-five pairs of filaments. In this specimen the filaments are not quite fully relaxed: in life those of the proximal whorls were straight to the tips. Essentially their arrangement is already that of the fully formed adult spirolophe. Those behind the mouth project anteroventrally and touch the ventral mantle. The lateral and anterior filaments on the proximal whorls are long and project outwards. Near the median plane they shorten abruptly and interdigitate. On the incipient second whorls they are very short, and are shown strongly flexed in the frontal direction; but like the other filaments on this specimen they are not fully relaxed, and in the 
natural state they touch the body of the lophophore immediately behind them. The body of these incipient second whorls is strongly recurved against the anterior part of the proximal whorls. Thus the lophophore divides the mantle cavity into separate chambers as in the fully formed spirolophe, and the water currents follow the same paths.

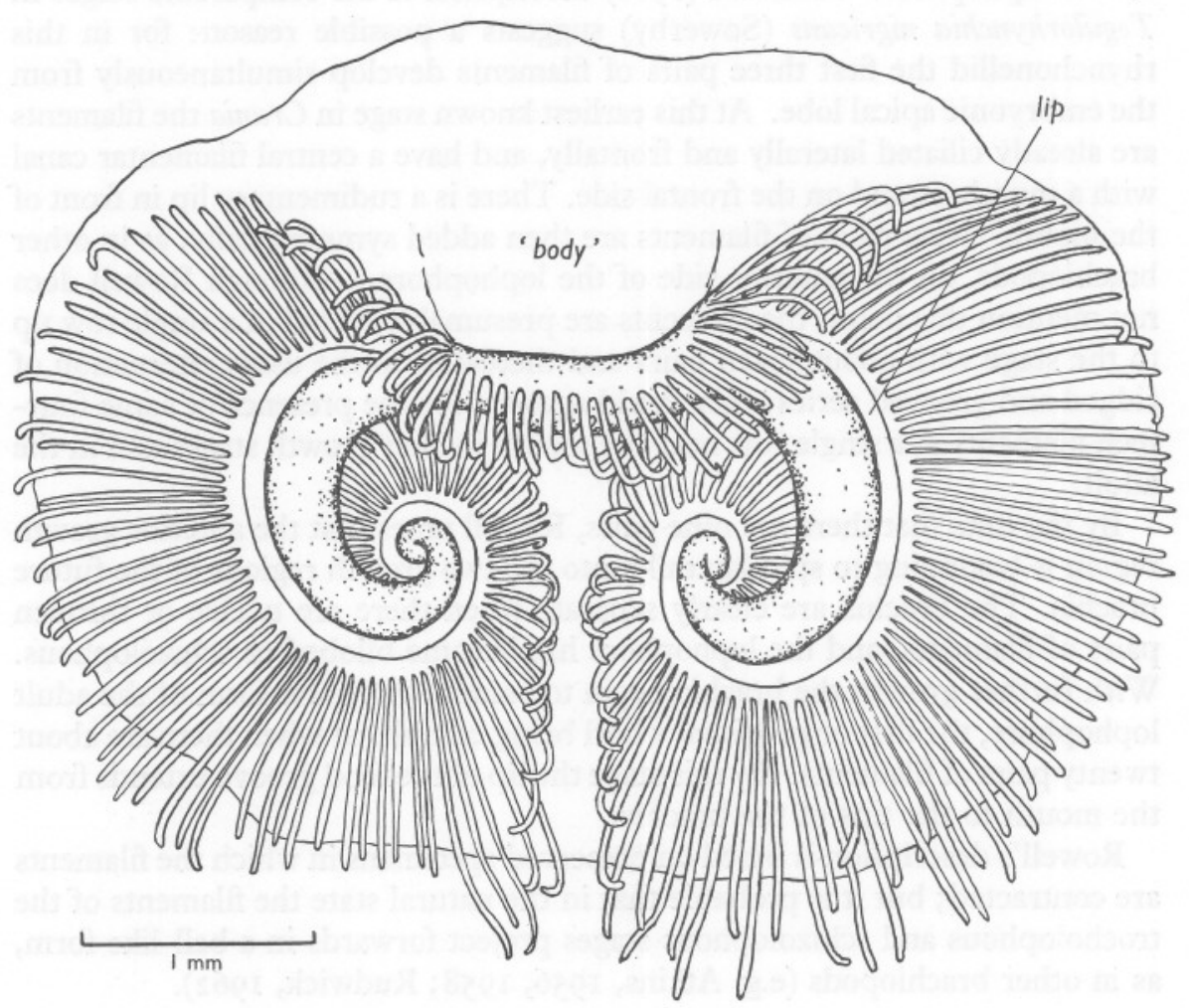

Fig. 4. Crania anomala: ventral view of early spirolophe, in dorsal valve of about $5 \mathrm{~mm}$ width; imperfectly narcotized before opening.

At the next stage figured (Fig. 4) the second whorls are complete. Owing to imperfect relaxation the tips of some of the filaments are slightly contracted (those near the median plane should interdigitate); otherwise the orientation is natural. The filaments of the second whorl on each brachium are flexed so that their tips touch the bases of the filaments on the proximal whorl; and at the terminal point of the brachium the body of the lophophore is tightly recurved as before. The second whorls are now clearly dorsal in position relative to the proximal whorls, thus forming the beginnings of the dorsally directed spirals. The water currents are the same as in the adult spirolophe (Fig. 2). Thus the growth of the lophophore through the spirolophous stage 
involves no more than the progressive lengthening of the brachia and proliferation of new filaments at the terminal growing points; this gradually enlarges the size of the spiral brachia and their number of whorls, but does not demand any fundamental changes in the system of filter-feeding water currents.

\section{COMPARISON WITH OTHER BRACHIOPODS}

\section{The ciliation of the filaments}

As mentioned earlier, Crania anomala was the first brachiopod in which the ciliary feeding mechanism was described, and Orton's pioneer work is confirmed, in the main, by the present study.

The first detailed account of ciliary feeding in an articulate species was Richards's (1952) study of Neothyris lenticularis (Deshayes). She believed that the mode of action of the lateral cilia, and hence of the whole lophophore, was radically different from that of Crania as described by Orton; and she saw in this a confirmation of Percival's (I944) view (based on an embryological argument which he later (I953) reversed) that the articulates were completely unrelated to the inarticulates. But since the time of Richards's work all other articulate species that have been studied (Atkins, 1956-6I ; Rudwick, I962) have been found to have a ciliary arrangement identical with that of Crania; and Neothyris itself has proved on re-investigation to be the same (Rudwick, 1962). The ciliary mechanism therefore offers no support for placing the articulates in a different phylum from the inarticulates. On the other hand their similarities do not necessarily imply evolutionary affinity, since an essentially similar ciliary feeding mechanism is shared (as Orton first pointed out) by many unrelated filter-feeding animals-lamellibranchs, gastropods, protochordates and polychaetes. Nevertheless, the uniformity in the structure of the filaments of brachiopods, and their cilia, is certainly remarkable. It would be difficult to distinguish, in sections, between the alternating ridged and grooved filaments of Crania and those of any articulate species (except by the presence of spicules in some of the latter). This is perhaps some support for the traditional view of the integrity of the phylum, though of course it is impossible to prove conclusively that even such detailed resemblances might not be convergent. The only anomalous species is now the inarticulate Lingula unguis (L.), in which Chuang (1956) reports that there are five adjacent tracts of frontal cilia, three beating towards the base of the filament and two towards the tip. On this point Lingula shows more similarity to the lamellibranchs than it does to all other brachiopods so far studied. Experience with ciliary feeding in lamellibranchs had led Atkins to expect that the apparent reversal of the frontal cilia in brachiopods would prove to be illusory and really due to adjacent tracts beating in different directions; and it was only after repeated re-examination that it became unavoidable to conclude that there was only a single tract of frontal cilia capable of genuine reversal 
(Atkins, I956). It is therefore most important that Chuang's conclusion should be confirmed by a very careful study of other species of Lingula and other lingulids such as Glottidia.

\section{The current-system}

The current-system (Rudwick, 1960) of $C$. anomala, like that of all other brachiopods that have been investigated, consists essentially of one-way flow through a mantle cavity which is completely divided by the lophophore into separate inhalant and exhalant chambers, with separate inhalant and exhalant apertures to the exterior.

Perhaps the most remarkable feature of the current-system is that it can be matched almost exactly with that of the rhynchonellid Tegulorhynchia nigricans (Rudwick, 1962). The orientation of the filaments is virtually identical: in Tegulorhynchia as in Crania the filaments of the proximal whorl project outwards while those of the distal whorls are flexed and touch the axis of the adjacent, more proximal whorl. In both species the lophophore thus divides the mantle cavity into separate chambers, the interior of the spirals being filled with inhalant water; in both the water enters the inhalant chamber by a pair of antero-lateral inhalant apertures, and emerges from the exhalant chamber by a single median and a pair of postero-lateral exhalant apertures (though the latter become very small in the final growth stages of Tegulorhynchia). Yet there can be little doubt that this detailed similarity is convergent: Crania is an inarticulate, Tegulorhynchia an articulate, each with the distinctive anatomical characters peculiar to their respective subphyla. The spirolophe of Crania is unsupported by skeletal structures, and the body of the lophophore is a highly muscular structure (see Blochmann, I892); the spirolophe of Tegulorhynchia is supported basally by skeletal crura and elsewhere only by a hydrostatic skeleton-the very thin-walled great brachial canal (see Atkins, 1962). This striking convergence in the filter-feeding system may reflect a fundamental inherent limitation on the variety of currentsystems which can possibly be produced by a spirolophe (see Rudwick, I960).

$T$. nigricans is at present the only spirolophous articulate species in which the current-system has been described; but Leidhold's figure (1922, Taf. XI, fig. I $a$ ) of a preserved but relaxed spirolophe of $T$. doederleini Davidson suggests that this species is similar. Although Hancock (1859) described the anatomy of Hemithyris psittacea Gmelin in great detail, the natural disposition of the spirolophe and its filaments is still unknown from living specimens.

Although the orientation of the spirals in Lingula unguis (Chuang, 1956) differs from that of Crania, the apices pointing medially, the current-system is essentially the same. The filaments of the proximal whorl project outwards away from the spiral axis, and touch the mantle surfaces; those on the distal whorls are flexed and touch the adjacent, more proximal whorl (Rudwick, I960, text-fig. $7 b$ ), although this orientation is not shown in Chuang's fig. 3 . 
Rowell (I96I) has suggested that the inarticulate Discinisca may be a living representative of a type of spirolophous current-system postulated by Rudwick (1960) for the extinct Spiriferoidea, in which the interior of the spirals would be filled with exhalant water, the direction of filtration being reversed from that found in Crania, Lingula and Tegulorhynchia. Should this be confirmed by observation on living specimens, it will add support to the theory of an inherent limitation on the possible variety of spirolophous current-systems.

\section{The development of the lophophore}

A close resemblance between Crania and the spirolophous articulate Tegulorhynchia exists not only in the form of the adult spirolophe and its current-system but also in the mode of development of the lophophore. In both, the filaments form a complete ring around the mouth in the earliest stages (Rowell, I960; Percival, I960). In both, the initial ring of the trocholophe is later modified into a bilobed schizolophe, while the initial growthregion (at which new filaments make their appearance) splits into the two terminal growth regions of the future brachia (Rowell, I960; Atkins, 1962). In both, the lobes of the schizolophe develop through further growth at their tips into the dorsally directed conical spirals of the spirolophe. This supports the concept of a limitation on the number of alternative developmental 'pathways' which can be followed during the growth of the lophophore: the trocholophe-schizolophe-spirolophe 'pathway' is one of only three alternatives found among living brachiopods (Rudwick, 1962).

The work described in this paper was done by D.A. while occupying a London University Table and in part with assistance from the Browne Research Fund of the Royal Society, and by M.J.S.R. while occupying a Cambridge University Table.

\section{SUMMARY}

Orton's account of ciliary mechanisms on the lophophore of Crania anomala (Müller) is confirmed. Observations on the natural orientation of the lophophore have modified his account of the filter-feeding water currents. As in other brachiopods the lophophore divides the mantle cavity into inhalant and exhalant chambers with separate apertures to the exterior. The inhalant chamber has two apertures, is ventral in position, and extends into the interior of the spiral brachia; the exhalant chamber is dorsal in position and has three apertures. The development of the lophophore in the later growth stages is described. Both in development and in the form and function of the organ in the adult, the lophophore of $C$. anomala closely resembles that of the articulate species Tegulorhynchia nigricans (Sowerby): it is suggested that this reflects an inherent limitation on the possible variety of lophophores in brachiopods. 


\section{REFERENCES}

Atkins, D., 1956. Ciliary feeding mechanisms of brachiopods. Nature, Lond., Vol. I77, pp. 706-7.

1958. A new species and genus of Kraussinidae (Brachiopoda) with a note on feeding. Proc. zool. Soc. Lond., Vol. 131, pp. 559-81.

— 1959a. The growth stages of the lophophore of the brachiopods Platidia davidsoni (Eudes Deslongchamps) and P. anomioides (Philippi), with notes on the feeding mechanism. F. mar. biol. Ass. U.K., Vol. 38, pp. I03-32.

- $1959 \mathrm{~b}$. The early growth stages and adult structure of the lophophore of Macandrevia cranium (Müller) (Brachiopoda, Dallinidae). F. mar. biol. Ass. U.K., Vol. 38, pp. 335-50.

- 1959c. The growth stages of the lophophore and loop of the brachiopod Terebratalia transversa (Sowerby). F. Morph., Vol. 105, pp. 40I-26.

— I 1960 a. A note on Dallina septigera (Lovén), (Brachiopoda, Dallinidae). F. mar. biol. Ass. U.K., Vol. 39, pp. 9I-9.

- $1960 \mathrm{~b}$. The ciliary feeding mechanism of the Megathyridae (Brachiopoda), and the growth stages of the lophophore. F. mar. biol. Ass. U.K., Vol. 39, pp. 459-79.

196I. The growth stages and adult structure of the lophophore of the brachiopods Megerlia truncata (L.) and M. echinata (Fischer and Oehlert). F. mar. biol. Ass. U.K., Vol. 4I, pp. 95-III.

- 1962. Notes on the lophophore and gut of Tegulorhynchia (Notosaria) nigricans (Sowerby) (Brachiopoda). Proc. zool. Soc. Lond. (in the Press).

BlochmanN, F., 1892. Untersuchungen über den Bau der Brachiopoden, I. 65 pp. Jena: Gustav Fischer.

Bulman, O. M. B., 1939. Muscle systems of some inarticulate brachiopods. Geol. Mag., Vol. 76, pp. 434-44.

ChUANG, S. H., 1956. The ciliary feeding mechanisms of Lingula unguis (L.) (Brachiopoda). Proc. zool. Soc. Lond., Vol. 127, pp. 167-89.

Hancock, A., I859. On the organization of the Brachiopoda. Phil. Trans., B, Vol. I48, pp. $79 \mathrm{I}-869$.

LeIDHOLD, C., 1922. Rhynchonella doederleini Dav., eine kritische Brachiopodenuntersuchung. Neues fb. Miner. Geol. Paläont., Bd. 45, pp. 423-70.

OrTON, J. H., I9I4. On ciliary mechanisms in brachiopods and some polychaetes, with a comparison of the ciliary mechanisms on the gills of molluscs, Protochordata, brachiopods, and cryptocephalous polychaetes, and an account of the endostyle of Crepidula and its allies. F. mar. biol. Ass. U.K., Vol. Io, pp. 283-3I I.

Percival, E., I944. A contribution to the life history of the brachiopod Terebratella inconspicua Sow. Trans. roy. Soc. N.Z., Vol. 74, pp. I-23.

— I953. Orientation of telotrematous Brachiopoda. Nature, Lond., Vol. I71, p. 436. I960. A contribution to the life-history of the brachiopod Tegulorhynchia nigricans. Quart. F. micr. Sci., Vol. I0I, pp. 439-57.

Richards, J. R., I952. The ciliary feeding mechanisms of Neothyris lenticularis (Desh.). F. Morph., Vol. 90, pp. 65-9I

Rowell, A. J., I960. Some early growth stages in the development of the brachiopod Crania anomala (Müller). Ann. Mag. nat. Hist., Ser. 13, Vol. 3, pp. 35-52.

- 196r. Inhalant and exhalant feeding current systems in recent brachiopods. Geol. Mag., Vol. 98, pp. 26I-3.

RUDwICK, M. J. S., I960. The feeding mechanisms of spire-bearing fossil brachiopods. Geol. Mag., Vol. 97, pp. 369-83.

- 1962. Filter-feeding mechanisms in some brachiopods from New Zealand. Proc. Linn. Soc. (Zool.), Vol. 44, pp. 592-615. 